\title{
REGIO- AND STEREOSPECIFIC CONSTRUCTION OF VICINAL QUATERNARY CARBONS: TOTAL SYNTHESIS OF ( \pm )-ALBENE
}

\author{
ADUSUMILli SRIKRISHNA* and SANKURATRI NAGARAJU \\ Department of Organic Chemistry, Indian Institute of Science, Bangalore 560012, India \\ (Received in revised form 3 July 1995)
}

\section{IN HONOUR OF PROFESSOR ANTONIO G. GONZALEZ}

Key Word Index-Albene; quaternary carbons; Claisen rearrangement; diazo ketone; cyclopropanation; reductive cycopropane cleavage; Shapiro reaction.

\begin{abstract}
A regiospecific and stereoselective total synthesis of the trisnorsesquiternene ( \pm )-albene, via a prochiral precursor is described. The ortho ester Claisen rearrangement of the allyl alcohol, obtained in two regiospecific reactions from a Diels-Alder adduct, followed by hydrolysis of the resultant ester furnished an ene acid in a highly stereoselective manner. Anhydrous copper sulphate catalysed intramolecular cyclopropanation reaction of the diazo ketone derived from the ene acid, generated a cyclopropyl ketone. The regiospecific reductive cleavage of this cyclopropyl ketone resulted in a prochiral ketone. Finally, Shapiro reaction on the tosylhydrazone, derived from the latter ketone, furnished $( \pm$ )-albene.
\end{abstract}

\section{INTRODUCTION}

The optically active crystalline hydrocarbon albene (1), a trisnorsesquiterpene containing a unique exo-2,6dimethyltricyclo[5.2.1.0 $\left.0^{2,6}\right]$ decane carbon framework incorporating two vicinal quaternary carbon atoms, was first isolated in 1962 by Novotny et al. [1] from the plant, Petasites albus. Later, it was found to be ubiquitous in species of the genera Petasites (white pestilence weed) and Adenostyles. This deceptively simple looking molecule has an interesting chemical history. The earliest structural studies carried out on albene showed it to be a tricyclic hydrocarbon with a disubstituted double bond in a five membered ring, for which Sorm et al. [2] proposed, provisionally the tetrahydrotriquinacene structure 2. In 1972 the tetrahydrotriquinacene structure was revoked [3] based on chemical degradation and correlation with camphene, and the endo structure 3 (now referred to as isoalbene) was assigned to albene. Later in 1978, the correct stereostructure of albene as exo-2,6-dimethyltricyclo[5.2.1.0 $\left.0^{2,6}\right]$ undec-3-ene (1) was established conclusively, largely due to the efforts of Kreiser and coworkers [4-6] via the total synthesis of the endo-isomer and reinterpretation of earlier results. Since the assignment of correct stereostructure to albene four research groups [7-10], Baldwin (1981), Trost (1982), Dreiding (1983) and Curran (1987) have reported the total synthesis of albene (1), prior to the initiation of work in the authors' laboratory $[11,12]$. The unique exo-2,6dimethyltricyclo[5.2.1. $\left.0^{2,6}\right]$ decane skeleton with two

*Author to whom correspondence should be addressed.

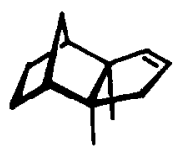

$\perp$

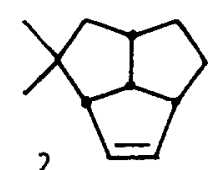

2

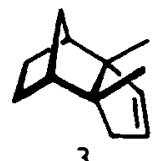

3 vicinal quaternary carbon atoms makes albene an interesting synthetic target. Herein we report the details of a regiospecific total synthesis of $( \pm)$-albene via a prochiral precursor.

\section{RESULTS AND DISCUSSION}

In the authors' laboratory a general methodology was developed [13] for the annulation of a cyclopentane ring with two vicinal quaternary carbon atoms starting from allyl alcohols based on ortho ester Claisen rearrangement [14] and diazo ketone cyclopropanation [15] reactions. The presence of two vicinal quaternary carbon atoms with methyl substituents prompted the extension of this methodology for the total synthesis of albene via the prochiral ketone 4 . The retro synthetic analysis (Scheme 1) of albene (1) based on the ortho ester Claisen rearrangement and intramolecular diazo ketone cyclopropanation reactions readily identified the prochiral ketone 4, cyclopropyl ketone 5 and ene-acid 6 as the requisite precursors. The allyl alcohol $7[16,17]$ was chosen as the starting material in anticipation that the acetate side chain will be introduced from the exo face of the norbornane moiety during the Claisen rearrangement which will result in the endo orientation for the tert-methyl group as required. The allyl alcohol 7 


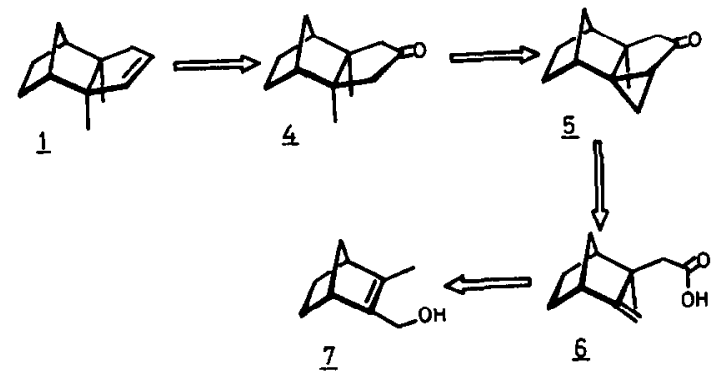

Scheme 1. Retro synthetic analysis of albene.

was prepared in a straightforward manner starting from cyclopentadiene. Since the Diels-Alder reaction of cyclopentadiene with methyl tetrolate resulted in low yield of the adduct 8 , Diels-Alder reaction was carried out using tetrolic acid. Thus reaction of cyclopentadiene and tetrolic acid in a sealed tube at $140^{\circ}$ for $5 \mathrm{hr}$, followed by esterification of the adduct 9 with an excess of ethereal diazomethane furnished the ester 8 in $80 \%$ yield. The regiospecific hydrogenation of the less substituted olefin of the ester 8, using 10\%-Pd/C as catalyst in ethyl acetate at atmospheric pressure of hydrogen, furnished the dihydro derivative, the ester 10 . Since the reaction of the ester 10 with LAH was found to generate a mixture of allyl and saturated alcohols, it was reduced with diisobutylaluminium hydride (DIBAH) in toluene at $-78^{\circ}$ to furnish the allyl alcohol 7 , the requisite starting material for the Claisen rearrangement, in $92 \%$ yield (Scheme 2).

The first quaternary carbon atom of albene was introduced using a highly stereoselective ortho ester Claisen rearrangement [14]. Thus, thermal activation of a solution of the allyl alcohol 7 and a catalytic amount of propionic acid in triethyl ortho-acetate for $48 \mathrm{hr}$ at $180^{\circ}$ generated the ene-ester 11 [16] in $81 \%$ yield, whose structure was delineated from its spectral data. The sterically preferred exo transition state 12 over the endo transition state 13 explains the exclusive formation of the exo product 11. The long reaction time required for this rearrangement was drastically reduced by employing a microwave oven [18]. Thus, microwave irradiation of a solution of the allylic alcohol 7, triethyl ortho-acetate and a catalytic amount of propionic acid in dry DMF in a clean Erlenmeyer flask for $14 \mathrm{~min}$ in a commerical microwave oven furnished the ester 11 in $87 \%$ yield. Hydrolysis of the ester 11 using 20\% aqueous sodium hydroxide in methanol furnished the key intermediate of the sequence, the ene-acid 6, m.p. $85-87^{\circ}, 76 \%$ yield.

The second quaternary carbon atom was created employing a copper catalysed intramolecular diazo ketone cyclopropanation reaction [15]. Reaction of the acid 6 with oxalyl chloride in benzene at room temperature furnished the acid chloride 14 which on treatment with an excess of freshly prepared ethereal diazomethane at $0^{\circ}$ generated the diazo ketone 15. Anhydrous copper sulphate catalysed decomposition of the diazo ketone 15 in refluxing cyclohexane, using a $100 \mathrm{~W}$ tungsten lamp for

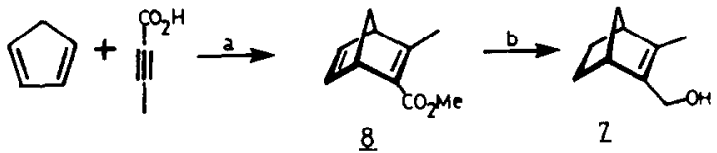

Scheme 2. (a) i $140^{\circ}$, sealed tube, $5 \mathrm{hr}$; ii $\mathrm{CH}_{2} \mathrm{~N}_{2}, \mathrm{Et}_{2} \mathrm{O}$. (b) i $\mathrm{H}_{2}-10 \% \mathrm{Pd} / \mathrm{C}, 1 \mathrm{~atm}, 1.5 \mathrm{hr}$; ii DIBAH, PhMe, $-78^{\circ}, 1 \mathrm{hr}$.
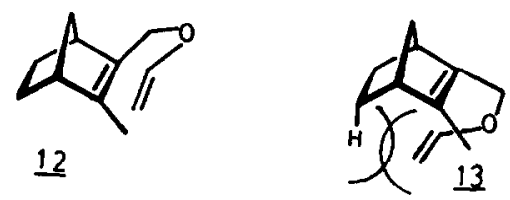

$5 \mathrm{hr}$, generated the cyclopropyl ketone 5 in $53 \%$ yield (from acid 6) via the intramolecular insertion of the resultant keto carbenoid into the exo-methylene whose structure rests secured from its spectral data (Scheme 3). The preferential formation of the cyclopropyl ketone 5 was a consequence of the insertion of the ketocarbenoid from the exo face of the molecule as it cannot approach from the other face of the double bond. This forces the cyclopropyl methylene to occupy the endo position, namely cis with respect to the endo tert-methyl group, thus creating the two quaternary centres in a highly stereoselective manner. The cyclopropyl ketone 5 was then transformed into the prochiral ketone 4 , by the regiospecific cleavage of the $\mathrm{C}_{3}-\mathrm{C}_{4}$ bond of the cyclopropane ring. Thus, reduction of the cyclopropyl ketone 5 using lithium in liquid ammonia for $15 \mathrm{~min}$ at $-33^{\circ}$, regiospecifically furnished the prochiral ketone 4 in $81 \%$ yield generating the second endo tert-methyl group. Both the ${ }^{1} \mathrm{H}$ and ${ }^{13} \mathrm{C}$ NMR (seven lines) spectra clearly revealed the presence of a plane of symmetry in the molecule. The regiospecificity in the cyclopropane ring cleavage can be readily explained [19] as it is well established that in the reduction of cyclopropyl ketones with lithium in liquid ammonia, of the two possibilities, the cyclopropane bond which is having maximum overlap with the p-orbital of the carbonyl system will be cleaved. Alternate to the reduction with lithium in liquid ammonia, catalytic hydrogenation $\left(40 \mathrm{psi}(\approx 276 \mathrm{kPa}), \mathrm{H}_{2}\right.$ $10 \% \mathrm{Pd} / \mathrm{C}$, methanol, $5 \mathrm{hr}$ ) of the less substituted cyclopropane bond also transformed the cyclopropyl ketone 5 into the prochiral ketone 4 in quantitative yield.

The last phase in the synthesis, i.e. conversion of the ketone 4 into albene, requires the transformation of a cyclopentanone to a cyclopentene. For this purpose, a Shapiro reaction $[20,21]$ on the corresponding tosylhydrazone was adopted. Thus, treatment of the ketone 4 with tosylhydrazide in refluxing ethanol for four hours formed the tosylhydrazone 16, m.p. $162^{\circ}$, in $86 \%$ yield. Finally, treatment of the tosylhydrazone 16 in $N, N, N^{\prime}, N^{\prime}$-tetramethylethylenediamine (TMEDA) and ether with an excess of $n$-butyllithium furnished $( \pm)$ albene (1), m.p. $110-115^{\circ}$ (lit. [1] $110-115^{\circ}$ ) in $65 \%$ yield. The ${ }^{1} \mathrm{H}$ and ${ }^{13} \mathrm{C}$ NMR spectra of our synthetic albene were found to be identical with those reported [5] in the literature for the natural product. 


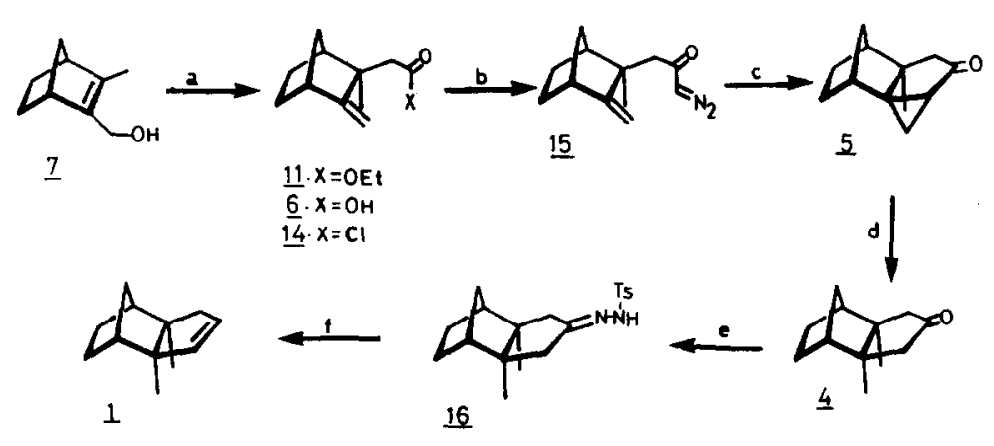

Scheme 3. (a) i MeC(OEt) $)_{3}$, EtCOOH; sealed tube, $180^{\circ}, 48 \mathrm{hr}$ or DMF, microwave irradiation, 14 min. (b) i Aq. $\mathrm{NaOH}, \mathrm{MeOH}, 70^{\circ}, 6 \mathrm{hr}$; ii $\mathrm{C}_{6} \mathrm{H}_{6},(\mathrm{COCl})_{2}, \mathrm{RT}, 2 \mathrm{hr}$. ii $\mathrm{CH}_{2} \mathrm{~N}_{2}, \mathrm{Et}_{2} \mathrm{O}, 2 \mathrm{hr}$. (c) Anhydrous $\mathrm{CuSO}_{4}, \mathrm{c}^{-\mathrm{C}_{6}} \mathrm{H}_{12}$, W-lamp, 5 hr. (d) Li-liquid $\mathrm{NH}_{3}, 15 \mathrm{~min}$ or $\mathrm{H}_{2}-10 \% \mathrm{Pd} / \mathrm{C}, 40 \mathrm{psi}, 5 \mathrm{hr}$. (e) $\mathrm{NH}_{2} \mathrm{NH}-\mathrm{Ts}$, EtOH, reflux, 4 hr. (f) $n$-BuLi, Et ${ }_{2} \mathrm{O}$, TMEDA, $0^{\circ}, 6 \mathrm{hr}$.

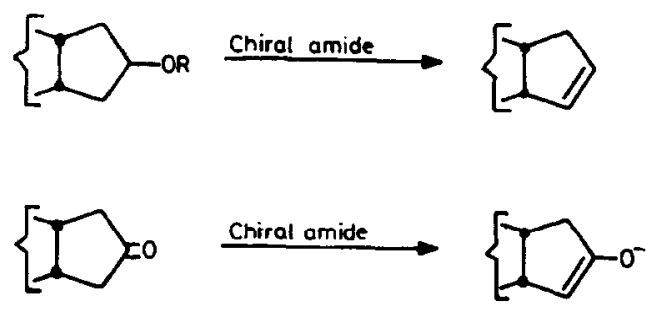

(oq. 1)

(eq. 2)

In conclusion, a stereoselective and regiospecific total synthesis of $( \pm)$-albene (1) was achieved via the prochiral ketone 4 using the ortho ester Claisen rearrangement and intramolecular diazo ketone cyclopropanation reaction as key steps for the construction of the two vicinal quaternary carbons. It is evident from the foregoing discussion that if a methodology is available for the converison of a prochiral cycloalkanone to a chiral cycloalkene, the ketone $\mathbf{4}$ can serve as a precursor to chiral albene. Recent reports on the conversion of prochiral ketones to chiral alkenes employing chiral amides [22] either for elimination [23] (equation 1) or generation of chiral enolates [24] (equation 2), enhanced the significance of the present synthesis, as a potential route to chiral albene.

\section{EXPERIMENTAL}

Melting points are not corrected. The chemical shifts $(\delta \mathrm{ppm})$ and coupling constants $(\mathrm{Hz})$ in ${ }^{1} \mathrm{H}(60$ and $90 \mathrm{MHz}$ ) and ${ }^{13} \mathrm{C} \mathrm{NMR}(22.5 \mathrm{MHz}$ ) spectra are reported with reference to either internal tetramethylsilane (for ${ }^{1} \mathrm{H}$ ) or central line (77.1 ppm) of $\mathrm{CDCl}_{3}$ (for ${ }^{13} \mathrm{C}$ ). In the ${ }^{13} \mathrm{C} \mathrm{NMR}$ spectra off-resonance multiplicities, when recorded are given in parentheses. Low- and high-resolution mass measurements were carried out using a direct inlet mode. Relative intensities of the ions are given in parentheses. Elemental analyses were carried out using a Carlo Erba 1106 analyser. Acme's silica gel (100-200 mesh) was used for column chromatography. Cyclopentadiene was freshly prepared by cracking dicyclopentadiene at $180^{\circ}$. Tetrolic acid and $N$-nitroso- $N$-methylurea were prepared according to the reported procedures [25].
Methyl 3-methylbicyclo[2.2.1]hepta-2,5-diene-2-carboxylate (8)

(1) Diels-Alder reaction. A solution of tetrolic acid $(5 \mathrm{~g}, 59 \mathrm{mmols})$, freshly distilled cyclopentadiene $(5 \mathrm{~g}$, 75 mmols) and a catalytic amount of hydroquinone in toluene $(10 \mathrm{ml})$ was taken in a Carius tube in $\mathrm{N}_{2}$ and heated at $140^{\circ}$ for $5 \mathrm{hr}$. The Carius tube was cooled, saturated solution of aqueous $\mathrm{NaHCO}_{3}(50 \mathrm{ml})$ was added to the reaction mixture and washed with $\mathrm{CH}_{2} \mathrm{Cl}_{2}$ $(3 \times 30 \mathrm{ml})$ to remove the dicyclopentadiene and other oligomers. The aqueous phase was acidified with $10 \%$ aqueous $\mathrm{HCl}$ and extracted with $\mathrm{CH}_{2} \mathrm{Cl}_{2}(3 \times 30 \mathrm{ml})$. The $\mathrm{CH}_{2} \mathrm{Cl}_{2}$ layer was washed with water and brine, and dried $\left(\mathrm{Na}_{2} \mathrm{SO}_{4}\right)$. Evaporation of the solvent and filteration of the residue through a silica gel $(5 \mathrm{~g})$ column using $\mathrm{CH}_{2} \mathrm{Cl}_{2}$ as eluant furnished the adduct $9(\approx 8 \mathrm{~g})$ as a dark low melting solid. ${ }^{1} \mathrm{H}$ NMR $\left(90 \mathrm{MHz}, \mathrm{CDCl}_{3}\right)$; $\delta 6.92$ and $6.72\left(2 \mathrm{H}, d\right.$ of $\mathrm{AB} q, J_{5,6}=4.5 \mathrm{~Hz}$, $J_{1,6}=J_{4,5}=3 \mathrm{~Hz}, \mathrm{H}-5$ and 6), $3.90(1 \mathrm{H}$, br s, H-4), 3.41 $\left(1 \mathrm{H}\right.$, br s, H-1), $2.29\left(3 \mathrm{H}, s\right.$, olefinic $\left.\mathrm{CH}_{3}\right), 2.31$ and $1.99\left(2 \mathrm{H}, t\right.$ of $\mathrm{AB} q, J_{7 \mathrm{a}, 7 \mathrm{~b}}=9 \mathrm{~Hz}, J_{1,7}=J_{4,7}=2 \mathrm{~Hz}$, $\mathrm{H}-7)$.

(2) Esterification. The acid 9, obtained above, was taken in ether $(25 \mathrm{ml})$ and treated with freshly prepared [25] ethereal diazomethane (from $10 \mathrm{~g}$ of $N$-nitroso- $N$ methylurea and $100 \mathrm{ml}$ of $50 \%$ aqueous $\mathrm{KOH}$ ). Careful evaporation of the solvent and excess diazomethane followed by purification of the residue over a small silica gel $(5 \mathrm{~g})$ column using hexane as eluant furnished the ester $8(7.75 \mathrm{~g}, 80 \%)$ as an oil [17]. IR (neat): $v_{\max } \mathrm{cm}^{-1} 3070$ $(=\mathrm{C}-\mathrm{H}), 1713(\mathrm{C}=\mathrm{O}), 1635(\mathrm{C}=\mathrm{C}), 1437,1341,1320$, 1296, 1239, 1194, 1101, 1068. ${ }^{1} \mathrm{H}$ NMR (60 $\left.\mathrm{MHz}, \mathrm{CCl}_{4}\right)$ : $\delta 6.60-7.00(2 \mathrm{H}, m$, olefin), $3.90(1 \mathrm{H}, b r s, \mathrm{H}-4), 3.72(3 \mathrm{H}, s$, O-CH $\left.{ }_{3}\right), 3.40(1 \mathrm{H}, b r s, \mathrm{H}-1), 2.23\left(3 \mathrm{H}, s\right.$, olefinic $\left.\mathrm{CH}_{3}\right)$, $2.00(2 \mathrm{H}, m, \mathrm{H}-7) .{ }^{13} \mathrm{C}$ NMR (22.5 $\mathrm{MHz}, \mathrm{CDCl}_{3}$ ): $\delta 169.5(s, \mathrm{O}-\mathrm{C}=\mathrm{O}), 165.8(s, \mathrm{C}-3), 143.8(d)$ and $140.1(d)(\mathrm{C}-5$ and 6), $137.9(s, \mathrm{C}-2), 70.7(t, \mathrm{C}-7)$, $57.8(d, C-4), 50.8\left(q, \mathrm{O}-\mathrm{CH}_{3}\right), 50.5(d, \mathrm{C}-1), 16.9(q$, $\mathrm{C}_{3}-\mathrm{CH}_{3}$ ). (10).

Methyl 3-methylbicyclo[2.2.1]hept-2-en-2-carboxylate

To a solution of the ester $8(6 \mathrm{~g}, 36.5 \mathrm{mmol})$ in EtOAc $(15 \mathrm{ml})$ was added $10 \%-\mathrm{Pd} / \mathrm{C}(60 \mathrm{mg})$ and stirred under 
hydrogen atmosphere (balloon) for $1.5 \mathrm{hr}$. The reaction mixture was then filtered through a small silica gel $(5 \mathrm{~g})$ column. Evaporation of the solvent furnished the hydrogenated ester $10(6 \mathrm{~g}, 99 \%)$ as an oil. IR (neat): $v_{\max } \mathrm{cm}^{-1}$ $1713(\mathrm{C}=\mathrm{O}), 1632(\mathrm{C}=\mathrm{C}), 1437,1359,1281,1257,1203$, $1161,1092,1056 .{ }^{1} \mathrm{H}$ NMR $\left(60 \mathrm{MHz}, \mathrm{CCl}_{4}\right): \delta 3.63(3 \mathrm{H}, s$, O-CH $\left.{ }_{3}\right), 3.15$ (1H, br s, H-4), $2.75(1 \mathrm{H}$, br s, C-1), 2.16 $\left(3 \mathrm{H}, s\right.$, olefinic $\left.\mathrm{CH}_{3}\right), 0.95-1.90(6 \mathrm{H}, m, \mathrm{H}-5,6$ and 7$)$. ${ }^{13} \mathrm{C} \mathrm{NMR}\left(22.5 \mathrm{MHz}, \mathrm{CDCl}_{3}\right): \delta 165.8(s, \mathrm{O}-\mathrm{C}=\mathrm{O}), 160.0$ $(s, \mathrm{C}-3), 131.8(s, \mathrm{C}-2), 50.4\left(q, \mathrm{O}-\mathrm{CH}_{3}\right), 49.9(d, \mathrm{C}-4), 45.9$ $(t, C-7), 43.1(d, C-1), 26.2(t)$ and $24.4(t)(C-5$ and 6$), 14.4$ $\left(q\right.$, olefinic $\left.\mathrm{CH}_{3}\right)$.

(3-Methylbicyclo[2.2.1]hept-2-en)-2-methanol (7). To a cold $\left(-78^{\circ}\right)$ magnetically stirred solution of the ester $10(5.5 \mathrm{~g}, 33 \mathrm{mmol})$ in dry toluene $(25 \mathrm{ml})$ was added a solution of DIBAL-H (1.2M in toluene, $30 \mathrm{ml}, 36 \mathrm{mmol})$ and the reaction was allowed to attain room temperature over a period of $1 \mathrm{hr}$. The reaction was then quenched with water. The solids were filtered off and the residue was washed with ether $(25 \mathrm{ml})$. The combined organic phase was dried $\left(\mathrm{Na}_{2} \mathrm{SO}_{4}\right)$ and the solvent was evaporated. Purification of the residue on a silica gel $(15 \mathrm{~g})$ column using EtOAc-hexane (1:9) as eluant furnished the alcohol $7(4.2 \mathrm{~g}, 92 \%)$ as an oil [17]. IR (neat): $v_{\max } \mathrm{cm}^{-1} 3340(\mathrm{OH}), 1692,1446,1278,993 .{ }^{1} \mathrm{H}$ NMR $\left(90 \mathrm{MHz}, \mathrm{CDCl}_{3}\right): \delta 4.21$ and $4.00(2 \mathrm{H}, \mathrm{AB} q, J=12.6 \mathrm{~Hz}$, $\left.\mathrm{CH}_{2} \mathrm{OH}\right), 2.90(1 \mathrm{H}, b r s)$ and $2.60(1 \mathrm{H}, b r s)(\mathrm{H}-1$ and 4$)$, $1.68\left(3 \mathrm{H}, s\right.$, olefinic $\left.\mathrm{CH}_{3}\right), 0.90-1.70(6 \mathrm{H}, \mathrm{m}, \mathrm{H}-5,6$ and 7$)$. ${ }^{13} \mathrm{C} \mathrm{NMR}\left(22.5 \mathrm{MHz}, \mathrm{CDCl}_{3}\right): \delta 140.0(s)$ and $139.1(s)$ (olefinic), $57.4\left(t, \mathrm{CH}_{2} \mathrm{OH}\right), 47.8(d)$ and $43.5(d)(\mathrm{C}-1$ and 4), $46.6(t, C-7), 26.6(t)$ and $25.3(t)(C-5$ and 6$), 11.8(q$, $\mathrm{CH}_{3}$ ). EIMS: $m / z 138\left(37 \%, \mathrm{M}^{+}\right), 121(50), 110(70), 95$ (100), 91 (46).

Ethyl exo-(2-methyl-3-methylenebicyclo[2.2.1]heptane)-2acetate (11)

Method A. A solution of the allylic alcohol $7(4 \mathrm{~g}$, $28.9 \mathrm{mmol})$, triethyl orthoacetate $(6 \mathrm{ml}, 32.8 \mathrm{mmols})$ and a catalytic amount of propionic acid were taken in a Carius tube in $\mathrm{N}_{2}$ and heated at $180^{\circ}$ for $48 \mathrm{hr}$. The reaction mixture was cooled, diluted with ether $(30 \mathrm{ml})$, washed with $0.5 \mathrm{M} \mathrm{HCl}$ followed by saturated $\mathrm{NaHCO}_{3}$ solution and brine, and dried $\left(\mathrm{Na}_{2} \mathrm{SO}_{4}\right)$. Evaporation of the solvent and purification of the residue on a silica gel $(20 \mathrm{~g})$ column using EtOAc-hexane $(1: 40)$ as eluent furnished the ester $11(4.9 \mathrm{~g}, 81 \%)$ as an oil [16].

Method B. A solution of the alcohol $7(110 \mathrm{mg}$, $0.8 \mathrm{mmol})$, triethyl orthoacetate $(3 \mathrm{ml}, 16.4 \mathrm{mmol})$ and propionic acid (catalytic) in dry DMF $(3 \mathrm{ml})$ in a $25 \mathrm{ml}$ flask was placed in a microwave oven and irradiated for $14 \mathrm{~min}$. After the completion of the irradiation, work-up and purification as described above furnished the ester 11 (144 mg, 87\%).

IR (neat): $v_{\max } \mathrm{cm}^{-1} 3070(=\mathrm{C}-\mathrm{H}), 1735(\mathrm{O}-\mathrm{C}=\mathrm{O})$, $1662(\mathrm{C}=\mathrm{C}), 1230,1200,1152,1134,1116,1095,1030,880$ $\left(\mathrm{C}=\mathrm{CH}_{2}\right) . \quad{ }^{1} \mathrm{H}$ NMR $\left(90 \mathrm{MHz}, \mathrm{CDCl}_{3}\right): \delta 4.78(1 \mathrm{H}, s)$ and $4.52(1 \mathrm{H}, s)$ (olefinic), $4.12(2 \mathrm{H}, q, J=7.2 \mathrm{~Hz}$, $\left.\mathrm{O}-\mathrm{CH}_{2} \mathrm{CH}_{3}\right), 2.70(1 \mathrm{H}, b r s)$ and $2.42(1 \mathrm{H}, b r s)(\mathrm{H}-1$ and 4), 2.42 and $2.16\left(2 \mathrm{H}, \mathrm{AB} q, J=15 \mathrm{~Hz}, \mathrm{CH}_{2}-\mathrm{CO}\right)$,
$1.30-1.90(6 \mathrm{H}, m, \mathrm{H}-5,6$ and 7$), 1.26(3 \mathrm{H}, t, J=7.2 \mathrm{~Hz}$, $\left.\mathrm{O}-\mathrm{CH}_{2} \mathrm{CH}_{3}\right), \quad 1.18\left(3 \mathrm{H}, \quad s\right.$, tert-Me). ${ }^{13} \mathrm{C}$ NMR $\left(22.5 \mathrm{MHz}, \mathrm{CDCl}_{3}\right): \delta 171.7(s, \mathrm{O}-\mathrm{C}=\mathrm{O}), 164.3(s$, $\left.\underline{\mathrm{C}}=\mathrm{CH}_{2}\right), 100.8\left(t, \mathrm{C}=\mathrm{CH}_{2}\right), 59.8\left(t, \mathrm{O}-\mathrm{CH}_{2} \mathrm{CH}_{3}\right), 46.8(d$, $\left.\mathrm{C}-1), 44.8(d, \mathrm{C}-4), 45.2\left(t, \mathrm{CH}_{2}-\mathrm{C}=\mathrm{O}\right), 44.0(s, \mathrm{C}-2)\right), 37.0$ $(t, \mathrm{C}-7), 29.2(t)$ and $23.5(t)(\mathrm{C}-5$ and 6$), 22.8\left(q, \mathrm{C}_{3}-\mathrm{CH}_{3}\right)$, $14.3\left(q, \mathrm{O}-\mathrm{CH}_{2} \mathrm{CH}_{3}\right)$. EIMS: $m / z 208\left(19 \%, \mathrm{M}^{+}\right), 134$ (20), 121 (84), 120 (70), 105 (40), 93 (100), 91 (70). HRMS: $m / z 208.1455$ (Calcd for $\mathrm{C}_{13} \mathrm{H}_{20} \mathrm{O}_{2}: 208.1463$ ).

exo-(2-Methyl-3-methylenebicyclo[2.2.1] heptane)-2acetic acid (6). To a solution of the ester $11(4.2 \mathrm{~g}$, $20.19 \mathrm{mmol})$ in methanol $(20 \mathrm{ml})$ was added an aqueous solution of $\mathrm{NaOH}(4 \mathrm{~g}$ in $20 \mathrm{ml})$ and magnetically stirred at $70^{\circ}$ for $6 \mathrm{hr}$. The reaction mixture was then acidified with $10 \% \mathrm{HCl}$ and extracted with ether $(3 \times 30 \mathrm{ml})$. The ether layer was washed with water followed by brine and dried $\left(\mathrm{Na}_{2} \mathrm{SO}_{4}\right)$. Evaporation of the solvent and purification of the residue over a silica gel $(5 \mathrm{~g})$ column using $\mathrm{CH}_{2} \mathrm{Cl}_{2}$ as eluant gave the acid $6(2.75 \mathrm{~g}, 76 \%)$ which was recrystallized from hexane- $\mathrm{CH}_{2} \mathrm{Cl}_{2}$. m.p.: 85-87 . IR (nujol): $v_{\max } \mathrm{cm}^{-1} 3000$ (br, OH), $1707(\mathrm{O}-\mathrm{C}=\mathrm{O}), 1242$, 935, $888\left(\mathrm{C}=\mathrm{CH}_{2}\right) .{ }^{1} \mathrm{H}$ NMR $\left(90 \mathrm{MHz}, \mathrm{CDCl}_{3}\right): \delta 4.83$ $(1 \mathrm{H}, s)$ and $4.57(1 \mathrm{H}, s)$ (olefinic), $2.70(1 \mathrm{H}$, br s, $\mathrm{H}-4), 2.48$ $(1 \mathrm{H}$, br $s, \mathrm{H}-1), 2.48$ and $2.27(2 \mathrm{H}, \mathrm{AB} q, J=16 \mathrm{~Hz}$, $\left.\mathrm{CH}_{2}-\mathrm{CO}\right), 1.30-1.80(6 \mathrm{H}, m, \mathrm{H}-5,6$ and 7$), 1.2(3 \mathrm{H}, s$, tert- $\left.\mathrm{CH}_{3}\right) .{ }^{13} \mathrm{C} \mathrm{NMR}\left(22.5 \mathrm{MHz}, \mathrm{CDCl}_{3}\right): \delta 179.0(s$, $\mathrm{O}-\mathrm{C}=\mathrm{O}), 164.5\left(s, \underline{\mathrm{C}}=\mathrm{CH}_{2}\right), 101.3\left(t, \mathrm{C}=\mathrm{CH}_{2}\right), 46.9(d)$ and $45.0(d)(C-1$ and 4$), 45.5(t, C-7), 44.2(s, C-2), 37.3(t$, $\left.\mathrm{CH}_{2} \mathrm{COOH}\right), 29.3(t)$ and $23.7(\mathrm{C}-1$ and $\mathrm{C}-4), 23.1(q$, tert- $\mathrm{CH}_{3}$ ). (Found: $\mathrm{C}, 73.46 ; \mathrm{H}, 9.08 . \mathrm{C}_{11} \mathrm{H}_{16} \mathrm{O}_{2}$ requires C, $73.30 ; \mathrm{H}, 8.95 \%)$.

\section{7-Methyltetracyclo $\left[6.2 .1 .0^{2,4} \cdot 0^{2,7}\right]$ undecan-5-one (5)}

(1) Acid chloride (14). A solution of the acid $6(2.5 \mathrm{~g}$, $13.8 \mathrm{mmol}$ ) and oxalyl chloride ( $2 \mathrm{ml}, 23.2 \mathrm{mmols})$ in dry benzene $(5 \mathrm{ml})$ was magnetically stirred at room temperature for $2 \mathrm{hr}$. Evaporation of the solvent and excess oxalyl chloride under reduced pressure afforded the acid chloride 14 which was immediately used for the preparation of the diazo ketone.

(2) Diazo ketone (15). A solution of the acid chloride 14 , obtained above, in dry ether $(10 \mathrm{ml})$ was added dropwise with stirring to a cold ethereal solution of diazomethane (excess, prepared from $15 \mathrm{~g}$ of $N$-nitroso- $N$ methylurea and $50 \mathrm{ml}$ of $50 \%$ aqueous $\mathrm{KOH}$ ). The reaction mixture was stirred at room temperature for $2 \mathrm{hr}$, and the ether and excess diazomethane were removed by careful evaporation on a water bath. Filtration of the residue rapidly through a neutral alumina $(8 \mathrm{~g})$ column using EtOAc-hexane $(1: 20)$ as eluant furnished the diazo ketone $15(2.2 \mathrm{~g}, 78 \%)$ as a viscous yellow oil. IR (neat): $v_{\max } \mathrm{cm}^{-1} 3075(=\mathrm{C}-\mathrm{H}), 2105$ (diazo), $1635(\mathrm{C}=\mathrm{O}), 1455$, $1359,1053,880 .{ }^{1} \mathrm{H}$ NMR $\left(60 \mathrm{MHz}, \mathrm{CCl}_{4}\right): \delta 5.08(1 \mathrm{H}, s$, $\left.\underline{\mathrm{HC}}=\mathrm{N}_{2}\right), 4.65(1 \mathrm{H}, s)$ and $4.41(1 \mathrm{H}, s)$ (olefinic), $2.66(1 \mathrm{H}$, br $s, \mathrm{H}-4), 2.50(1 \mathrm{H}, b r s, \mathrm{H}-1), 2.05$ and $2.35(2 \mathrm{H}, \mathrm{AB} q$, $\left.J=14 \mathrm{~Hz}, \mathrm{CH}_{2}-\mathrm{C}=\mathrm{O}\right), 1.00-2.00(6 \mathrm{H}, m, \mathrm{H}-5,6$ and 7$)$, $1.13\left(3 \mathrm{H}, \mathrm{s}\right.$, tert $\left.-\mathrm{CH}_{3}\right)$.

(3) Cyclopropyl ketone (5). A solution of the diazo ketone 15 obtained above was taken in dry cyclohexane 
$(25 \mathrm{ml})$ and added dropwise, over a period of $0.5 \mathrm{hr}$, to a refluxing (using a $100 \mathrm{~W}$ tungsten lamp placed at $2^{\prime \prime}$ $\left(1^{\prime \prime} \approx 25.4 \mathrm{~mm}\right.$ ) from the reaction flask), magnetically stirred suspension of anhydrous $\mathrm{CuSO}_{4}(4.5 \mathrm{~g})$ in cyclohexane $(80 \mathrm{ml})$, and stirred at reflux for $5 \mathrm{hr}$. The reaction mixture was cooled and the $\mathrm{CuSO}_{4}$ was filtered off using a sintered funnel. Evaporation of the solvent and purification of the residue on a silica gel $(20 \mathrm{~g})$ column using EtOAc-hexane $(1: 20)$ as eluant furnishd the tetracyclic ketone $5(1.3 \mathrm{~g}, 53 \%$ from acid 6) as a waxy, low melting solid. IR (neat): $v_{\max } \mathrm{cm}^{-1} 1730(\mathrm{C}=\mathrm{O}), 1470,1296,1236$, 1206, 957. ${ }^{1} \mathrm{H}$ NMR $\left(90 \mathrm{MHz}, \mathrm{CDCl}_{3}\right): \delta 2.48$ and 2.02 $\left(2 \mathrm{H}, \mathrm{AB} q, J=18 \mathrm{~Hz}, \mathrm{CH}_{2}-\mathrm{C}=\mathrm{O}\right), 2.16(1 \mathrm{H}$, br $s, \mathrm{H}-4)$, 1.20-2.00 $(10 \mathrm{H}, m), 0.98\left(3 \mathrm{H}, s\right.$, tert $\left.-\mathrm{CH}_{3}\right) .{ }^{13} \mathrm{C} \mathrm{NMR}$ $\left(22.5 \mathrm{MHz}, \mathrm{CDCl}_{3}\right): \delta 215.1(s, \mathrm{C}=\mathrm{O}), 56.0\left(t, \mathrm{CH}_{2} \mathrm{CO}\right)$, $50.8(s, \mathrm{C}-7), 48.2(d)$ and $42.0(d)$ (C-1 and 8), 40.5 (s, C-2), $37.7(t, \mathrm{C}-11), 35.2(d, \mathrm{C}-4), 25.0(2 \mathrm{C}, t, \mathrm{C}-9$ and 10$), 23.1$ ( $q$, $\left.\mathrm{C}_{7}-\mathrm{Me}\right), 17.2(t, \mathrm{C}-3)$. EIMS: $m / z 176\left(31 \%, \mathrm{M}^{+}\right), 148(45$, $\mathrm{M}^{+}$-CO), 121 (45), $120(51), 106(42), 105(30), 93$ (100), 91 (60), 79 (52). HRMS: $m / z$ 176.1195. (Calcd. for $\mathrm{C}_{12} \mathrm{H}_{16} \mathrm{O}$ 176.1201).

exo-2,6-Dimethyltricyclo $\left[5.2 .1 .0^{2,6}\right]$ decan-4-one (4).

Method $A$. To a magnetically stirred, freshly distilled ammonia $(150 \mathrm{ml})$ in a three necked flask equipped with a Dewar condenser, was added the cyclopropyl ketone 5 (1.12 g, $6.4 \mathrm{mmol})$ in dry ether ( $5 \mathrm{ml})$, followed by freshly cut lithium $(175 \mathrm{mg}, 25 \mathrm{mmol})$. The reaction mixture was stirred at $-33^{\circ}$ for $15 \mathrm{~min}$, quenched with solid $\mathrm{NH}_{4} \mathrm{Cl}$ and the ammonia was slowly evaporated. The residue was taken in water $(30 \mathrm{ml})$ and extracted with ether $(3 \times 30 \mathrm{ml})$. The ether extract was washed with brine and dried $\left(\mathrm{Na}_{2} \mathrm{SO}_{4}\right)$. Evaporation of the solvent and purification of the residue over a silica gel $(15 \mathrm{~g})$ column using EtOAc-hexane $(1: 20)$ as eluent furnished the prochiral ketone $4(908 \mathrm{mg}, 81 \%)$, as a low meiting solid.

Method B. A suspension of the cyclopropyl ketone 5 (40 mg, $0.23 \mathrm{mmol})$ and $10 \%-\mathrm{Pd} / \mathrm{C}(10 \mathrm{mg})$ in methanol $(5 \mathrm{ml})$ was placed in a $250 \mathrm{ml}$ pressure bottle and hydrogenated at $40 \mathrm{psi}(\approx 276 \mathrm{kPa})$ for $5 \mathrm{hr}$ in a Parr-type hydrogenation apparatus. The catalyst was filtered off using a Buchner funnel. Evaporation of the solvent furnished the prochiral ketone $4(40 \mathrm{mg}, 99 \%)$.

IR $\left(\mathrm{CCl}_{4}\right): v_{\max } \mathrm{cm}^{-1} 1737(\mathrm{C}=\mathrm{O}), 1404,1386,1092$, 624. ${ }^{1} \mathrm{H}$ NMR (90 MHz, $\left.\mathrm{CDCl}_{3}\right): \delta 2.32\left(4 \mathrm{H}, s, 2 \times \mathrm{CH}_{2}-\right.$ $\mathrm{CO}), 1.90(2 \mathrm{H}, b r s, \mathrm{H}-1$ and 7$), 1.20-1.80(6 \mathrm{H}, m, \mathrm{H}-5$, 6 and 7), $1.12\left(6 \mathrm{H}, s, 2 \times\right.$ tert $\left.-\mathrm{CH}_{3}\right),{ }^{13} \mathrm{C}$ NMR $(22.5 \mathrm{MHz}$, $\left.\mathrm{CDCl}_{3}\right): \delta 219.5(\mathrm{~s}, \mathrm{C}=\mathrm{O}), 55.4\left(2 \mathrm{C}, t, \mathrm{CH}_{2}-\mathrm{C}=\mathrm{O}\right), 50.5$ (2C, $d, \mathrm{C}-1$ and 7), 46.2 (2C, s, C-2 and 6), 34.8 ( $t, \mathrm{C}-10$ ), $23.7(2 \mathrm{C}, t, \mathrm{C}-7$ and 8$), 21.1\left(2 \mathrm{C}, q, 2 \times\right.$ tert $\left.-\mathrm{CH}_{3}\right)$. EIMS: $m / z 178\left(80 \%, \mathbf{M}^{+}\right), 150\left(30, \mathrm{M}^{+}-\mathrm{CO}\right), 135(100), 121$ (37), 109 (40), 108 (55), 107 (96), 95 (76), 94 (90), 93 (80). HRMS: $m / z$ 178.1364. (Calcd. for $\mathrm{C}_{12} \mathrm{H}_{18} \mathrm{O} 178.1358$ ).

exo-2,6-Dimethyltricyclo[5.2.1.0 2,6]dec-4-ene (albene 1).

(1) Tosylhydrazone (16). A magnetically stirred solution of the ketone $4(535 \mathrm{mg}, 3 \mathrm{mmol})$ and tosylhydrazide $(600 \mathrm{mg}, 3.2 \mathrm{mmol})$ in ethanol $(5 \mathrm{ml})$ was refluxed for $4 \mathrm{hr}$. Solvent was then evaporated under reduced pressure and the crude product was purified on a silica gel ( $4 \mathrm{~g})$ column using EtOAc-hexane $(1: 9)$ as eluant to furnish the hydrazone $16(890 \mathrm{mg}, 86 \%)$ which was recrystallized from hexane- $\mathrm{CH}_{2} \mathrm{Cl}_{2}$. m.p.: $162^{\circ}$ (decomp.). IR $\left(\mathrm{CCl}_{4}\right)$ : $v_{\max } \mathrm{cm}^{-1} 3268(\mathrm{NH}), 1680(\mathrm{C}=\mathrm{N}), 1467,1440,1401$, 1341, 1305, 1158, 1086, 1020, 621. ${ }^{1} \mathrm{H}$ NMR $(90 \mathrm{MHz}$, $\left.\mathrm{CDCl}_{3}\right): \delta 7.74$ and $7.22\left(4 \mathrm{H}, \mathrm{A}_{2} \mathrm{~B}_{2} q, J=7.5 \mathrm{~Hz}\right.$, aromatic), $2.36(3 \mathrm{H}, s, \mathrm{Ar}-\mathrm{Me}), 2.20(2 \mathrm{H}, b r s)$ and $1.76(2 \mathrm{H}$, br s) (H-3 and 5), $1.00-1.50(8 \mathrm{H}, m), 0.90(6 \mathrm{H}, s, 2 \times$ tert $\left.\mathrm{CH}_{3}\right) .{ }^{13} \mathrm{C} \mathrm{NMR}\left(22.5 \mathrm{MHz}, \mathrm{CDCl}_{3}\right): \delta 168.5(\mathrm{C}=\mathrm{N})$, 143.8, 135.7, 129.6 (2C) and 127.9 (2C) (aromatic), 50.5, $50.3(2 \mathrm{C}), 49.0,47.0,44.9,34.5,23.6,23.4,21.7,21.0(2 \mathrm{C})$.

(2) Shapiro reaction. To a magnetically stirred, cold $\left(0^{\circ}\right)$ solution of the tosylhydrazone $16(800 \mathrm{mg}, 2.3 \mathrm{mmol})$ in dry ether $(5 \mathrm{ml})$ and TMEDA $(2.5 \mathrm{ml})$ was added a solution of $n$-butyllithium $(1.6 \mathrm{M}$ in hexanes, $4 \mathrm{ml}$, $6.4 \mathrm{mmol}$ ). The reaction mixture was stirred for $6 \mathrm{hr}$ at 0 , then quenched with wet ether, acidified with $\mathrm{HCl}(0.5 \mathrm{M})$ and extracted with ether $3 \times 10 \mathrm{ml}$ ). The ether extract was washed with saturated aqueous $\mathrm{NaHCO}_{3}$ and brine, and dried $\left(\mathrm{Na}_{2} \mathrm{SO}_{4}\right)$. Careful evaporation of the solvent followed by purification of the residue on a silica gel $(3 \mathrm{~g})$ column using pentane as eluant furnished $( \pm$ )-albene $(1$, $245 \mathrm{mg}, 65 \%$ ) as a white solid which was sublimed at $60^{\circ} / 50-60 \mathrm{~mm}$. m.p.: $110-115^{\circ}$ (Lit.[1] $110-115^{\circ}$ ). ${ }^{1} \mathrm{H}$ NMR $\left(90 \mathrm{MHz}, \mathrm{CDCl}_{3}\right): \delta 5.57$ and $5.27(2 \mathrm{H}, t$ of AB $q, J_{3.4}=7 \mathrm{~Hz}, J_{3.5}=J_{4.5}=2 \mathrm{~Hz}$, olefinic $), 2.23(2 \mathrm{H}, t$, $\left.J=2 \mathrm{~Hz}, \quad \mathrm{CH}_{2}-\mathrm{CH}=\right), 1.80(2 \mathrm{H}$, br $s, \mathrm{H}-1$ and 7$)$, $1.00-1.80(6 \mathrm{H}, m, \mathrm{H}-8,9$ and 10$), 0.96(6 \mathrm{H}, s, 2 \times$ tert$\left.\mathrm{CH}_{3}\right) .{ }^{13} \mathrm{C}$ NMR $\left(22.5 \mathrm{MHz}, \mathrm{CDCl}_{3}\right): \delta 139.7(d, \mathrm{C}-3)$, $128.4(d, C-4), 56.5(s, C-2), 51.9(t, C-5), 50.4(d)$ and 47.3 (d) (C-1 and 7), $46.8(s, \mathrm{C}-6), 34.3(t, \mathrm{C}-10), 24.0(2 \mathrm{C}, t, \mathrm{C}-8$ and 9), $20.8\left(q, \mathrm{C}_{6}-\mathrm{CH}_{3}\right), 18.2\left(q, \mathrm{C}_{2}-\mathrm{CH}_{3}\right)$.

Acknowledgement - One of the authors (SN) wishes to thank the Council of Scientific and Industrial Research, New Delhi for the award of a research fellowship.

\section{REFERENCES}

1. Hochmannova, J., Novotny, L. and Herout, V. (1962) Collect. Czech. Chem. Commun. 27, 2711.

2. Herout, V., Hochmannova, J. and Sorm, F. (1964) Angew. Chem. 76, 789.

3. Vokac, K., Samek, Z., Herout, V. and Sorm, F. (1972) Tetrahedron Lett. 1665.

4. Kreiser, W. and Janitschke, L. (1978) Tetrahedron Lett. 601.

5. Kreiser, W., Janitschke, L. and Ernst, L. (1978) Tetrahedron 34, 131.

6. Kreiser, W. and Janitschke, L. (1979) Chem. Ber. 112, 408.

7. Baldwin, J. E. and Barden, T. C. (1981) J. Org. Chem. 46, 2442.

8. Trost, B. M. and Renaut, P. (1982) J. Am. Chem. Soc. $104,6668$.

9. von Manzardo, G. G. G., Karpf, M. and Dreiding, A. S. (1983) Helv. Chim. Acta 66, 627.

10. Curran, D. P. and Chen, M.-H. (1987) J. Am. Chem. Soc. 109, 6558. 
11. Sonawane, H. R., Bellur, N. S., Ahuja, J. R. and Kulkarni, D. G. (1991) J. Org. Chem. 56, 1434.

12. Srikrishna, A. and Nagaraju, S. (1991) J. Chem. Soc., Perkin Trans. 1657.

13. Srikrishna, A. and Krishnan, K. (1993) J. Org. Chem. 58, 7751.

14. Johnson, W. S., Werthemann, L., Bartlett, W. R., Brocksom, T. J., Li, T. T., Faulkner, D. J. and Petersen, M. R. (1970) J. Am. Chem. Soc. 92, 741.

15. Stork, G. and Ficini, J. (1961) J. Am. Chem. Soc. 83, 4678.

16. Monti, H., Corriol, C. and Bertrand, M. (1982) Tetrahedron Lett. 23, 947.

17. Simmross, F.-M. and P. Weyerstahl, P. (1981) Liebigs Ann. Chem., 1089.

18. Srikrishna, A. and Nagaraju, S. (1992) J. Chem. Soc., Perkin Trans. 1311.
19. Srikrishna, A., Krishnan, K. and Yelamaggad, C. V. (1992) Tetrahedron 48, 9725.

20. Shapiro, R. H. and Heath, M. J. (1967) J. Am. Chem. Soc. 89, 5734.

21. Adlington, R. M. and Barrett, A. G. M. (1983) Acc. Chem. Res. 16, 55.

22. Cox, P. J. and Simpkins, N. S. (1991) Tetrahedron Asymm. 2, 1.

23. Kashihara, H., Suemune, H., Kawahara, T. and Sakai, K. (1990) J. Chem. Soc, Perkin Trans. I 1663.

24. Kim, H. -D., Kawasaki, H., Nakajima, M. and Koga, K. (1989) Tetrahedron Lett. 30, 6537.

25. Furness, B. S., Hannaford, A. J., Rogers, V., Smith, P. W. G. and Tatchell, A. R. (1978) Vogel's text book of Practical Organic Chemistry (4th edn). Longman, London. 